\title{
Mariusz Kowalski
}

\section{Morawianie (Morawcy) w Polsce}

W artykule podjęto charakterystykę ludności morawskiej (Morawców), która na skutek dwudziestowiecznych zmian terytorialnych zamieszkuje w granicach państwa polskiego. Przedstawiciele tej grupy wyróżniają się swym językiem (dialekt laski) i zwyczajami, jednak w odróżnieniu od mieszkańców Republiki Czeskiej, nie utożsamiają się z narodem morawskim lub czeskim. Uważają się za Polaków, Niemców lub Ślązaków, co wynika z przynależności państwowej tych ziem w latach 1742-2016. Procesy akulturacji sprawiają, że już niedługo mogą zniknąć ostatnie znamiona odrębności tej grupy etnicznej. O morawskim pochodzeniu będą świadczyły jedynie nazwiska, noszone przez część jej przedstawicieli.

Słowa kluczowe: Morawianie, dialekt laski, odrębność etniczna, Morawy, Śląsk, Polska.

\section{Wstęp}

W polsko-czeskich dysputach narodowościowych bardzo często pojawia się zagadnienie Zaolzia, tego fragmentu Śląska, który w wyniku politycznych rozstrzygnięć znalazł się w po pierwszej wojnie światowej w granicach Czechosłowacji, a obecnie wchodzi w skład Republiki Czeskiej. Znacznie rzadziej podejmowany jest problem części obszaru historycznych Moraw, która w 1945 r. znalazła się w granicach Polski, gdzie wciąż znajdują się skupiska ludności pochodzenia morawskiego. Do celów pracy zaliczono: przedstawienie okoliczności przyłączenia historycznych Moraw (morawskiego Śląska) do państwa polskiego, wyznaczenie zasięgu tego obszaru, ustalenie najważniejszych skupisk ludności morawskiej (Morawców), określenie ich przybliżonej liczebności oraz wstępną ocenę poczucia ich tożsamości etnicznej.

\section{Ewolucja granicy śląsko-morawskiej w średniowieczu}

Można niekiedy spotkać się z poglądami, że początkowo granica śląsko-polsko-(śląsko)-morawska przebiegała wododziałem Odry i Morawy, a więc m.in. grzbietem Jesioników (pasmo Sudetów) (np. Szydłowski 1991, Panic 2009) (ryc. 1). Dzisiejsza granica Czeskiego (Morawskiego) Śląska a Morawami 
również ma podobny przebieg, ale utrwaliła się dopiero w wyniku uznania Księstwa Opawskiego za część Śląska pod koniec średniowiecza, po dwóch wiekach przynależności ziemi opawskiej do Moraw. Przyjmując tę delimitację jako odniesienie dla podjętego tematu, żadna część historycznych Moraw i żadni Morawianie nie znajdowaliby się na obszarze dzisiejszej Polski. Jednak w 1137 r., w wyniku zawarcia pokoju w Kłodzku, kończącym długotrwałe wojny o przynależność Śląska, zawartym pomiędzy Bolesławem Krzywoustym a władcą Czech Sobiesławem I, linia graniczna została przesunięta na północ i ziemia opawska stała się częścią monarchii czeskiej (czeskich Moraw) (ryc. 1).

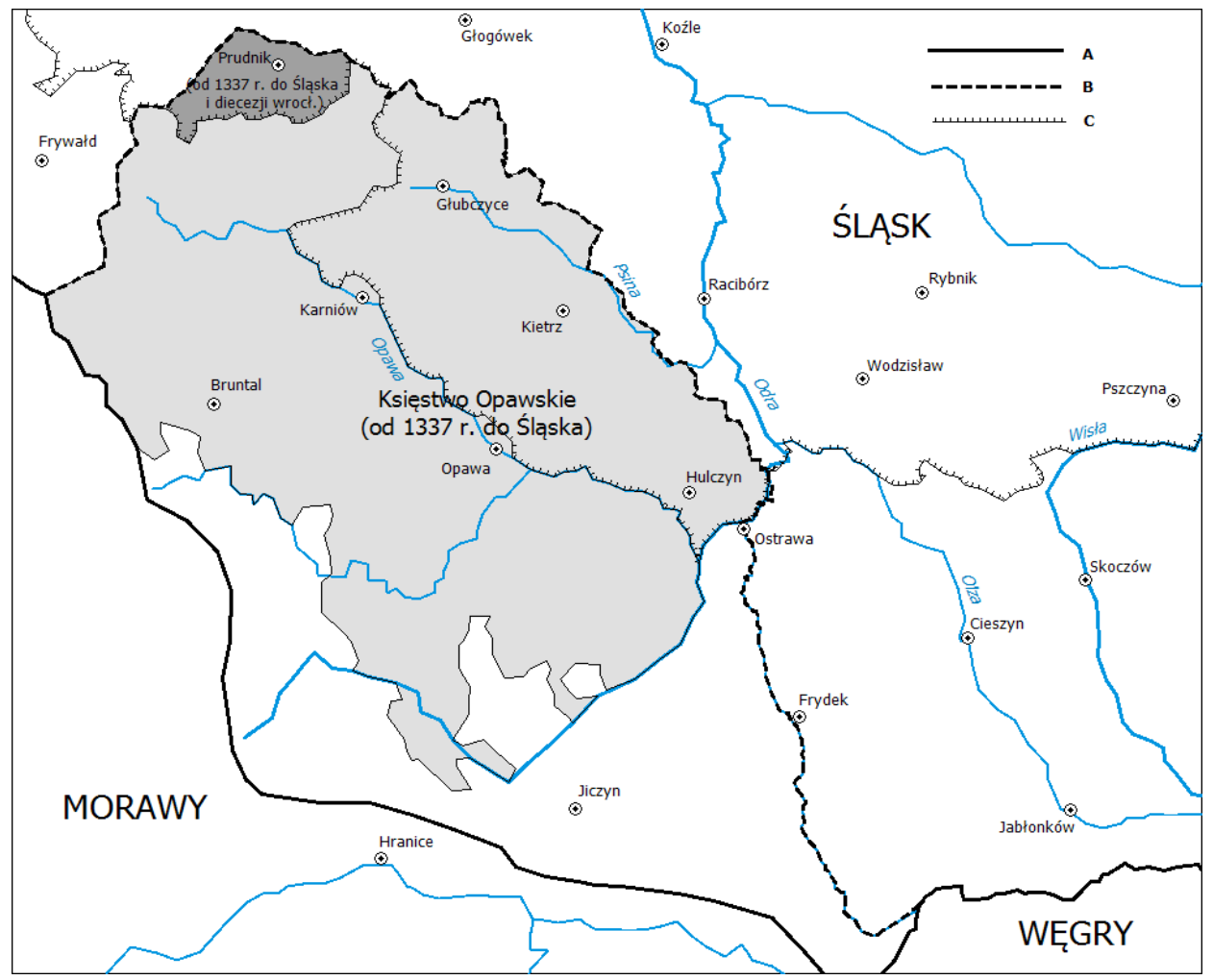

Ryc. 1. Ewolucja granicy śląsko-morawskiej do $1742 \mathrm{r}$.

A - przypuszczalne granice pierwotne, B - granica wyznaczona pokojem w Kłodzku

(1127 r.) i uszczegółowiona w 1261 r., C - granica prusko-austriacka z 1742 r. Źródło: opracowanie własne

Granica była jeszcze kilkakrotnie doprecyzowywana. W 1261 r. oparto ją ostatecznie na Ostrawicy (zachodnia granica Śląska Cieszyńskiego), a w 1337 r. do Śląska ponownie przyłączono ziemię prudnicką. Do tych polityczno-tery- 
torialnych rozwiązań dostosowano również granice diecezji. Obszar włączony do Korony Czeskiej (i Moraw) podlegał biskupowi ołomunieckiemu (morawskiemu), po północnej biskupowi wrocławskiemu (śląskiemu). Co prawda, Śląsk i diecezja wrocławska znalazły się w 1339 r. w obrębie Korony Czeskiej, jednak to właśnie podział diecezjalny stał się podstawą kształtowania ostatecznej granicy etnicznej pomiędzy Morawianami a Ślązakami. Działo się tak m.in. dlatego, że w diecezji ołomunieckiej kościół posługiwał się językiem czeskim, w diecezji wrocławskiej - polskim (Stieber 1934, Wrzosek 1955, Rospond 1959, Siatkowski 1994).

W późniejszym okresie, w północnej części Moraw wyodrębniło się Księstwo Opawskie (ryc. 1), które na skutek związków dynastycznych ich władców z książętami śląskimi uznano w XIV w. za część Śląska (Wendt 1978, Orzechowski 2005, Czapliński 2007, Gawrecká 2009). Nie miało to już jednak wpływu na rozgraniczenie diecezji i związane $\mathrm{z}$ nimi oddziaływania kulturowe, tym bardziej że Śląsk i Morawy wchodziły w skład tego samego organizmu politycznego - Korony św. Wacława. Duże znaczenie mogło mieć również to, że w Księstwie Opawskim (i wydzielonym z niego Karniowskim) obowiązywało prawo morawskie (i język czeski jako urzędowy), podczas gdy na Górnym Śląsku dość długo utrzymywało się prawo polskie (Kniejski, Sękowski 2012, Pałys 2012).

\section{Formowanie się języka i tożsamości regionalnej}

Uwarunkowania te sprawiły, że w północnych Morawach i wyodrębnionych na ich obszarze księstwach ukształtowały się ostatecznie narzecza laskie, stanowiące formę przejściową między dialektami śląskimi a morawskimi, najczęściej jednak zaliczane, razem z narzeczami czeskimi i morawskimi, do dialektów języka czeskiego (Stieber 1934, Dejna 1949). Odrębność językowa, tradycje prawne oraz przynależność do diecezji ołomunieckiej miały również wpływ na kształtowanie się świadomości terytorialnej tutejszej ludności. Nawet jeżeli zamieszkiwali włączone ostatecznie do Śląska Księstwa Opawskie i Karniowskie, uważali się i byli uważani za Morawian (Morawców). Za Morawian (Mährer) uważali się również zamieszkujący ten region Niemcy (Pałys 2006). Przynależność terytorialna miała znacznie większy wpływ na tożsamość mieszkańców niż język, jakim mówili. Mieszkańcy takich miejscowości, jak Raków, Tłustomosty, Sułków lub Dzielów (wszystkie w dzisiejszej gminie Baborów), choć mówili narzeczem śląskim (ryc. 2), także uważali się za Morawców. 


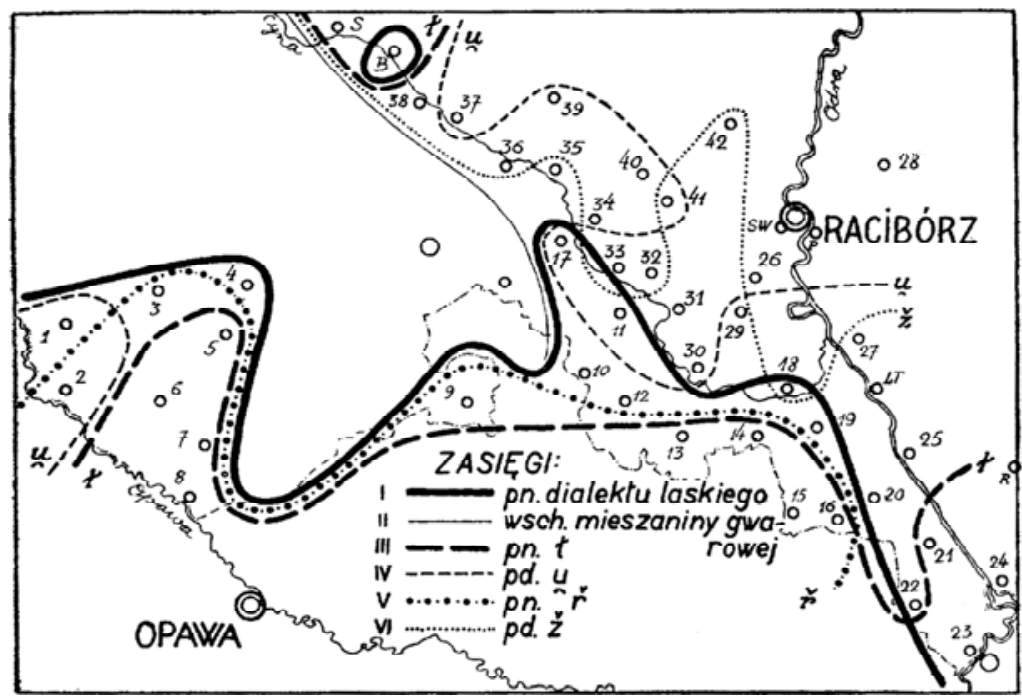

Ryc. 2. Zasięg dialektu laskiego w granicach Polski według Karola Dejny Źródło: K. Dejna (1949, s. 215)

1. Branice, 2. Boboluszki, 3. Wódka, 4. Chróścielów, 5. Nasiedle, 6. Jakubowice,

7. Uciechowice, 8. Wiechowice, 9. Ściborzyce, 10. Pietraszyn, 11. Samborowice,

12. Krzanowice, 13. Borucin, 14. Bolesław, 15. Owsiszcze, 16. Chałupki Ows.,

17. Pietrowice Wlk., 18. Bieńkowice, 19. Tworków, 20. Krzyżanowice, 21. Roszków, 22. Rudyszwałd, 23. Chałupki, 24. Olza, 25. Buków, 26. Studzienna, 27. Nieboczowy, 28. Markowice, 29. Sudoł, 30. Bojanów, 31. Wojnowice, 32. Lekartów, 33. Cyprzanów,

34. Kornice, 35. Maków, 36. Tłustomosty, 37. Raków, 38. Dzielów, 39. Krowiarki, 40. Pawłów, 41. Żerdziny, 42. Rudnik, S. Sułków, B. Baborów, SW. Stara Wieś, P. Płonia, LT. Ligota Twork., R. Rogowy

Z innej strony, mieszkańcy wsi Tworków i Bieńkowice (gmina Krzyżanowice), miejscowości leżących na obszarze historycznego Śląska i diecezji wrocławskiej, z Morawcami nigdy się nie utożsamiali (Dejna 1949), choć według językoznawców posługują się narzeczem laskim.

\section{Późniejsze podziały Śląska i śląskich Moraw}

Utrwalone w ramach Korony św. Wacława podziały terytorialne zostały zmienione w wyniku wojny austriacko-pruskiej. Większa część Śląska została przyłączona do Prus, mniejsza zaś pozostała częścią Królestwa Czech, rządzonego przez Habsburgów. Nowe rozwiązanie nie uwzględniło tradycyjnej granicy śląsko-morawskiej (ryc. 1). Przy monarchii habsburskiej pozostał Śląsk Cieszyński, odcięty od reszty historycznego regionu. Do Prus włączono zaś fragment dawnych Moraw (okolice Głubczyc i Hulczyna), podczas gdy zasadniczy trzon 
prowincji pozostał w monarchii habsburskiej jako część Korony Czeskiej (ryc. 1). Rozwiązanie to odcięło zamieszkujących państwo pruskie Morawian od wpływów czeskiego odrodzenia narodowego mającego miejsce w monarchii habsburskiej w XIX w. Razem ze Ślązakami zostali natomiast poddani narastającym procesom germanizacji. Sąsiedztwo obu grup oraz wspólne warunki rozwoju sprzyjały wzajemnemu zbliżeniu i rozwojowi śląskiej tożsamości regionalnej u Morawców (Pałys 2006, 2012, Mečiar 2007).

Kolejne zmiany terytorialne nastąpiły w wyniku pierwszej wojny światowej. Wschodnia część Śląska Cieszyńskiego przypadła Polsce, podczas gdy zachodnia weszła w skład Czechosłowacji. Podziałowi uległa również pruska część Moraw, którą analogicznie do Zaolzia, można by nazywać Zaopawiem (ryc. 3). Jego południowo-wschodnia część (okolice Hulczyna, cz. Hlučín), najbardziej morawska pod względem etnicznym, została włączona do Czechosłowacji. Pozostała część pozostała w obrębie Niemiec, by po 1945 r. zostać przyłączona do Polski. Ustalona w ten sposób granica istnieje do dzisiaj, poza przerwą w latach 1938-1945, gdy Zaolzie należało do Polski (w okresie 1939-1945 jedynie formalnie), a Śląsk Opawski do Niemiec.

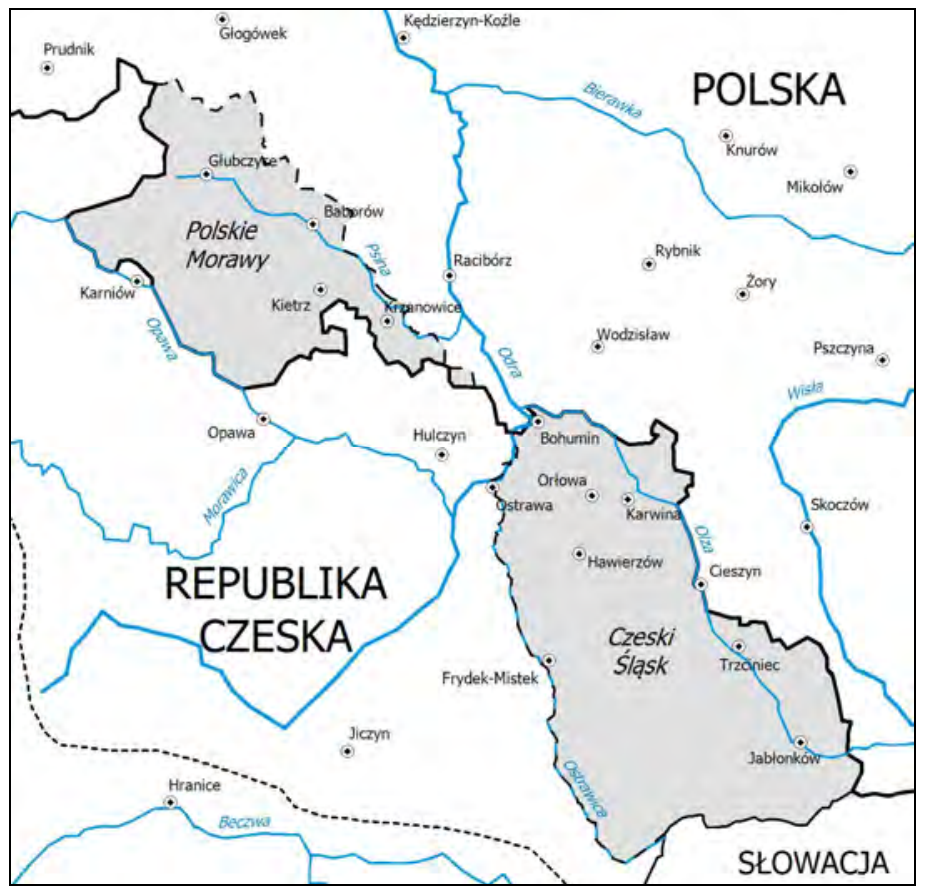

Ryc. 3. Polskie Morawy i czeski Śląsk. Linia przerywana - wododział dorzecza Odry i Morawy - wyznacza pierwotną (do 1137 r.) granicę między Morawami a Śląskiem Źródło: opracowanie własne 
W porównaniu z granicą austriacko-pruską z lat 1742-1918, obecne rozgraniczenie pomiędzy Polską a Republiką Czeską ma przebieg bardziej zbliżony do delimitacji między Śląskiem a Morawami wprowadzonej w średniowieczu. Niemniej fragment historycznego Śląska (dawna diecezja wrocławska) z ludnością częściowo polską (Zaolzie) należy do Republiki Czeskiej, podobnie fragment Moraw (dawna diecezje ołomuniecka) z wsiami zamieszkanymi przez tzw. Morawców wchodzi w skład Polski (ryc. 3).

\section{Morawy i Morawianie w Polsce po drugiej wojnie światowej}

Na polskie Morawy składa się prawie cały powiat głubczycki oraz fragmenty gmin Pietrowice Wielkie (cz. Velké Petrovice), Krzanów (cz. Křenovice) i Krzyżanowice (cz. Křižanovice) należących do powiatu raciborskiego (ryc. 3-4). Według pruskiego spisu ludności z 1910 r. żyło na tym obszarze ok. 14 tys. rdzennej ludności morawskiej (Klima 1925), przede wszystkim w trzech dzisiejszych gminach powiatu raciborskiego i północno-wschodniej (gmina Baborów, cz. Bavorov) oraz południowo-wschodniej (gmina Branice, cz. Bránice i Kietrz, cz. Ketř) części powiatu głubczyckiego (ryc. 4, tab. 1).

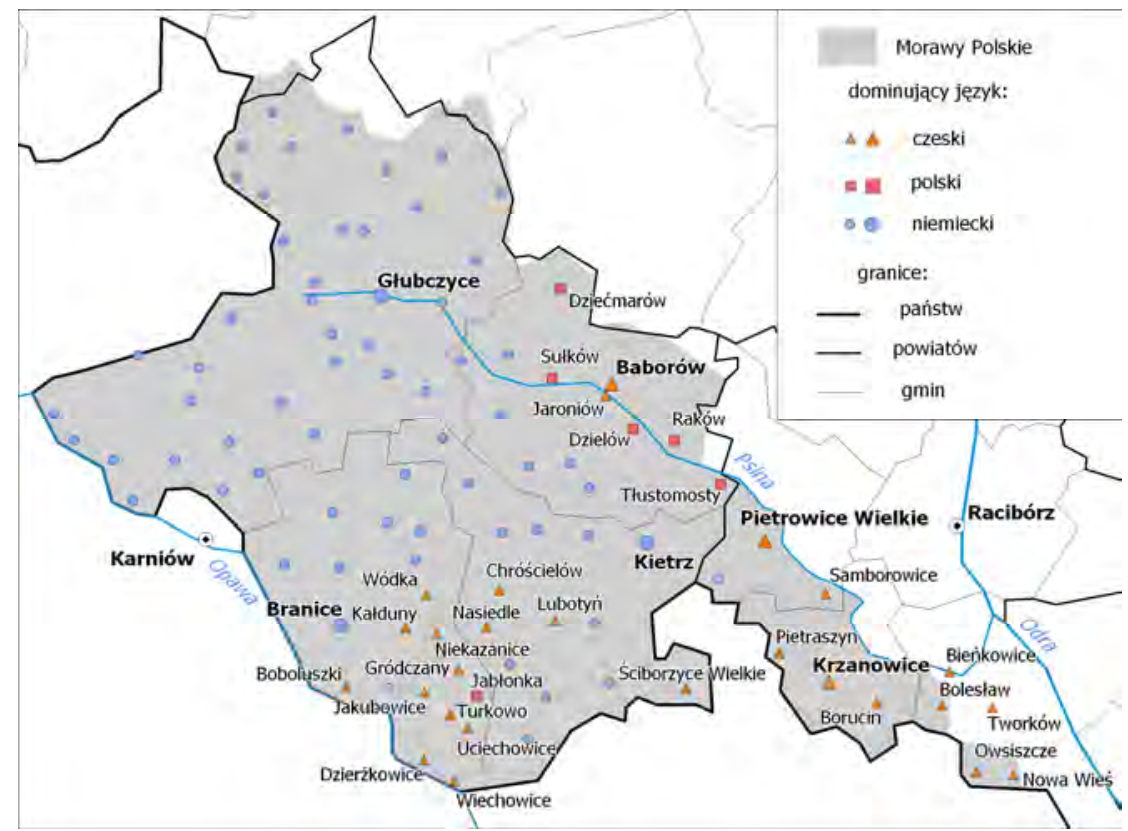

Ryc. 4. Język mieszkańców Polskich Moraw na początku XX w.

(wyróżniono ośrodki gminne)

Źródło: opracowanie własne 
Tabela 1. Wsie morawskie na obszarze dzisiejszej Polski z dużym odsetkiem ludności słowiańskiej na początku XX w. (w \%)

\begin{tabular}{|c|c|c|c|c|}
\hline \multicolumn{3}{|c|}{ Nazwa wsi } & \multirow{2}{*}{ Czesi } & \multirow{2}{*}{ Polacy } \\
\hline polska & czeska & niemiecka & & \\
\hline \multicolumn{5}{|c|}{ Powiat raciborski } \\
\hline Bieńkowice & Benkovice & Benkowitz & b.d. & 97 \\
\hline Bolesław & Boleslav & Boleslau & 92 & 5 \\
\hline Borucin & Bořutín & Borutin & 97 & 2 \\
\hline Gródczanki & Račanki & Ratsch & b.d. & b.d. \\
\hline Krzanowice & Křenovice & Kranowitz & 97 & 2 \\
\hline Nowa Wioska & Nova Veska & Neudörfel & b.d. & b.d. \\
\hline Owsiszcze & Ovsiště & Owschütz & b.d. & b.d. \\
\hline Pietraszyn & Petřatin & Klein Peterwitz & 96 & 0 \\
\hline Pietrowice Wielkie & Velké Petrovice & Gross Peterwitz & 61 & 18 \\
\hline Samborowice & Šamařovice & Schammerwitz & b.d. & b.d. \\
\hline Tworków & Tvorkov & Tworkau & b.d. & 95 \\
\hline \multicolumn{5}{|c|}{$\begin{array}{l}\text { Powiat głubczycki } \\
\end{array}$} \\
\hline Baborów & Bavorov & Bauerwitz & b.d. & b.d. \\
\hline Boboluszki & Bobolusky & Boblowitz & 48 & b.d. \\
\hline Branice & Bránice & Branitz & 18 & b.d. \\
\hline Chróścielów & Chrastilov & Krastillau & 74 & b.d. \\
\hline Dziećmarowy & Dětmárov & Dittmerau & b.d. & 75 \\
\hline Dzielów & Dèhylov & Eiglau & 34 & 46 \\
\hline Dzierżkowice & Držkovice & Dirschkowitz & 81 & b.d. \\
\hline Gródczany & Hradčany & Hratscheim & 77 & b.d. \\
\hline Jabłonka (Klemsztyn) & Klemštyn & Klemstein & 8 & 90 \\
\hline Jakubowice & Jakubovice & Jakubowitz & 79 & b.d. \\
\hline Jaroniów & Jaronov & Jernau & 11 & 64 \\
\hline Kałduny & Kaldouny & Kaldaunen & 71 & b.d. \\
\hline Lubotyń & Liptýně & Liptin & 36 & b.d. \\
\hline Ludmierzyce & Lidměřice & Leimerwitz & 12 & b.d. \\
\hline Nasiedle & Násile & Nassiedel & 60 & b.d. \\
\hline Niekazanice & Nekázanice & Osterwitz & 67 & b.d. \\
\hline $\begin{array}{l}\text { Pilszcz } \\
\end{array}$ & Pilšć & Poltsch & 7 & b.d. \\
\hline Raków & Rakov & Rackau & b.d. & 80 \\
\hline Sułków & Sulkov & Zülkowitz & b.d. & 75 \\
\hline Ściborzyce Wielkie & Štibořice & Steuberwitz & 91 & b.d. \\
\hline Tłustomosty & Tlustomosty & Stolzmütz & b.d. & 80 \\
\hline Turków & Turkov & Turkau & 74 & b.d. \\
\hline Uciechowice & Utěchovice & Auchwitz & 88 & b.d. \\
\hline Wiechowice & Vehovice & Wehowitz & 50 & b.d. \\
\hline Wódka & Vodka & Hochkretscham & 65 & b.d. \\
\hline Wysoka & Vysoká & Weissak & 9 & b.d. \\
\hline
\end{tabular}

Źródło: J. Wendt (1978), P. Pałys (2006). 
W XVII lub XVIII w. wsie z ludnością morawską znajdowały się jeszcze bardziej na zachód, jednak później uległy germanizacji (Wendt 1978, Janczak 1984). $Z$ tego względu w większości powiatu głubczyckiego przeważała ludność niemiecka (także podkreślająca swoje związki z Morawami), która po drugiej wojnie światowej została wysiedlona. Na jej miejsce napłynęła ludność polska z dawnych Kresów Wschodnich oraz z innych regionów Polski. Morawianie (Morawcy), którzy nie ulegli germanizacji, zostali przez władze polskie uznani za rodzimą ludność polską i pozwolono im pozostać. Ministerstwo spraw wewnętrznych szacowało ich liczbę na ok. 20 tys. (Kurek 1993).

Po 1956 r. rozpoczął się proces emigracji ludności morawskiej do Niemiec. Szczególnie silnie dotknął on południową część powiatu głubczyckiego, gdzie ludność morawska żyła w izolacji od ludności autochtonicznej pozostałej części Śląska (ryc. 4). Obecnie na tym obszarze pozostały jedynie pojedyncze rodziny pochodzenia morawskiego (Strauchmann 2008). Dość znaczący uszczerbek dotknął również północno-wschodnią część powiatu głubczyckiego (gmina Baborów). Już przed drugą wojną światową nastąpiła znacząca germanizacja Baborowa i idące za nią wysiedlenia większości jego mieszkańców po włączeniu do Polski. Późniejsze procesy emigracyjne dokonały dalszego osłabienia żywiołu morawskiego. Kolejnym elementem osłabiającym morawski charakter tego obszaru były zjawiska językowe. Jedynie gwarę Baborowa i sąsiedniego Jaroniowa (w 1926 r. włączonego do Baborowa) specjaliści zaliczali do dialektu laskiego, podczas gdy w innych miejscowościach gminy (Sułków, Raków, Dzielów, Tłustomosty, Dziećmarów) rodzima ludność posługiwała się dialektem śląskim (Dejna 1949). Można przypuszczać, że po drugiej wojnie światowej procesy te uległy nasileniu, podobnie jak umocnienie poczucia tożsamości śląskiej.

\section{Liczebność polskich Morawian}

Jednym z wyrazów odrębności mieszkańców polskich Moraw mogą być ich zachowania wyborcze. W ostatnich wyborach samorządowych (2014 r.) na mniejszość niemiecką i śląskich autonomistów głosowało w powiecie głubczyckim łącznie 447 wyborców (2,9\%). Po przeliczeniu na ogół ludności daje to ok. 1400 osób. W czasie spisu ludności w 2002 r. 776 osób zadeklarowało tu narodowość niemiecką, a 40 osób narodowość śląską (tab. 2). Deklaracji czeskich lub morawskich nie było lub liczyły mniej niż osiem przypadków (Deklarcaje...). Na tej podstawie można przypuszczać, że ludność rodzima (morawska) stanowiła w powiecie głubczyckim ok. 1500 osób, skoncentrowanych przede wszystkim w gminie Baborów. Ten stan rzeczy znajduje potwierdzenie w nazwiskach części tutejszych mieszkańców, występujących w Polsce jedynie na 
obszarze historycznych Moraw, i w dużej części wykazujących morawsko-czeskie pochodzenie (np. Affa, Fulneczek, Gotzman, Harnys, Koselek, Kolar, Kretek, Pospieszyl, Purszke, Zajczek, Źrały) (tab. 3).

Tabela 2. Struktura narodowości gmin „morawskich” lub częściowo „morawskich” według spisu $2002 \mathrm{r}$.

\begin{tabular}{|c|c|c|c|c|c|c|}
\hline \multirow{3}{*}{ Gminy } & \multicolumn{5}{|c|}{ Ludność } & \multirow{3}{*}{$\begin{array}{c}\text { Brak } \\
\text { deklaracji } \\
\text { (w \%) }\end{array}$} \\
\hline & \multirow{2}{*}{ ogółem } & \multicolumn{4}{|c|}{ według narodowości (w \%) } & \\
\hline & & Polacy & Niemcy & Ślązacy & inni & \\
\hline Baborów & 7050 & 87,06 & 8,65 & 0,57 & 0,13 & 3,59 \\
\hline Branice & 8020 & 94,34 & 0,85 & 0,00 & 0,11 & 4,70 \\
\hline Głubczyce & 24547 & 96,50 & 0,36 & 0,00 & 0,35 & 2,79 \\
\hline Kietrz & 12178 & 97,86 & 0,31 & 0,00 & 0,11 & 1,72 \\
\hline Krzanowice & 6264 & 53,43 & 20,64 & 7,10 & 0,05 & 18,77 \\
\hline Krzyżanowice & 11522 & 70,27 & 13,29 & 10,45 & 0,14 & 5,86 \\
\hline Pietrowice Wielkie & 7283 & 52,82 & 15,72 & 14,28 & 0,07 & 17,11 \\
\hline
\end{tabular}

Źródło: Deklaracje narodowościowe w gminach w 2002 roku ...

Oznaki morawskiej tożsamości utrzymują się najsilniej w trzech gminach powiatu raciborskiego. W 2002 r. 20-30\% mieszkańców tych gmin zadeklarowała narodowość niepolską, głównie niemiecką i śląską (tab. 2). Ludności rodzimej jest jednak z pewnością więcej, o czym świadczą wyniki wyborów. W 1991 r. na komitet Mniejszość Niemiecka głosowała tu ponad połowa wyborców (Pietrowice Wielkie - 67,3\%, Krzanowice - 75,1, Krzyżanowice 55,0\%). Gmina Krzanowice jest jedyną, która w większości składa się ze wsi morawskich. Tam też oddano najwięcej głosów na Mniejszość Niemiecką. Podobnie było, choć na niższym poziomie, w przypadku deklaracji narodowości niemieckiej w 2002 r. (tab. 2). Wyniki wyborów mogą świadczyć o tym, że ludność rodzima - w tym Morawcy - przeważała na początku lat 90. nad ludnością napływową w tej części polskich Moraw. W późniejszych wyborach odsetek głosów na komitet Mniejszości Niemieckiej stopniowo się zmniejszał, by w 2001 r. w trzech omawianych gminach wynieść 20-30\%, a więc tyle samo co odsetek ludności niepolskiej według spisu z 2002 r. Może to znaczyć, że Morawcy, podobnie jak Ślązacy, coraz silniej integrują się z polskim społeczeństwem, w większości deklarując narodowość polską i głosując na ogólnopolskie komitety wyborcze. Być może pewne znaczenie mają też procesy migracyjne (głównie emigracja do Niemiec), przy założeniu, że chętniej emigrowały osoby słabiej związane z polskością. 
Tabela 3. Nazwiska charakterystyczne dla polskich Moraw

\begin{tabular}{|c|c|}
\hline Nazwisko & Miejsce i liczba osób \\
\hline Affa & Dzielów (6), Raków (17), Tworków (10) \\
\hline Bedrunka & $\begin{array}{l}\text { Krzanowice (5), Borucin (5), Tworków (10), Bieńkowice (11), } \\
\text { Owsieszcze (22), }\end{array}$ \\
\hline Chrzibek & Tworków (10), Bieńkowice (5) \\
\hline Cwaigel & Krzanowice (5) \\
\hline Cziuraj (Czuraj) & Tworków (20), Bieńkowice (5) \\
\hline Dluhosch & Krzanowice (5), Borucin (5) \\
\hline Ehr & Krzanowice (5) \\
\hline Fas & Owsiszcze (11) \\
\hline Fichna & Owsiszcze (11), Krzanowice (10) \\
\hline Fojcik & $\begin{array}{l}\text { Borucin (26), Owsiszcze (16), Tworków (10), Krzanowice (5), } \\
\text { Samborowice (6), Pietrowice Wlk. (6), Raków (6), Gadzowice (6) }\end{array}$ \\
\hline Friedek & Tworków (16) \\
\hline Fulneczek & $\begin{array}{l}\text { Owsiszcze (11), Bieńkowice (16), Branice (5), Głubczyce (8), Mokre } \\
\text { (9), Zapowy (5) }\end{array}$ \\
\hline Hanczuch & Bieńkowice (11), Borucin (5) \\
\hline Hanka & Krzanowice (52), Borucin (5), Samborowice (6) \\
\hline Hanslik & Owsiszcze (5), Pietraszyn (15), Samborowice (6) \\
\hline Harnys (Harnyś) & Pietrowice Wlk. (6), Tłustomosty (9) \\
\hline Hawranek & Tworków (5) \\
\hline Herber & Krzanowice (10), Pietraszyn (10), Samborowice (6) \\
\hline Herud & Pietrowice Wlk. (34) \\
\hline Hnida & Krzanowice (21), Nieboczowy (6) \\
\hline Hluchnik & $\begin{array}{l}\text { Owsiszcze (5), Bieńkowice (5), Tworków (16), Burucin (16), } \\
\text { Krzanowice (10) }\end{array}$ \\
\hline Holubek & Borucin (16) \\
\hline Homola & Krzanowice (16) \\
\hline Horak & Pietrowice Wlk. (6) \\
\hline Jureczka & Krzanowice (83), Borucin (11), Owsieszcze (5) \\
\hline Kaszny & $\begin{array}{l}\text { Borucin (11), Krzanowice (10), Pietraszyn (5), Owsiszcze (5), } \\
\text { Tworków (10), Nieboczowy (6) }\end{array}$ \\
\hline Klemenz & Krzanowice (5) \\
\hline Kolar (Kollar) & Krzanowice (26), Borucin (5), Kietrz (5), Tworków (5) \\
\hline Kosel & Krzanowice (31) \\
\hline Koselek (Kosellek) & Baborów (8), Dzielów (13) \\
\hline Kral & Pietrowice Wlk. (6), Krzanowice (5), Borucin (5) \\
\hline Kretek & $\begin{array}{l}\text { Pietrowice Wlk. (17), Krzanowice (62), Borucin (26), Bieńkowice } \\
\text { (16), Tworków (42), Chrościelów (9) }\end{array}$ \\
\hline Kubny & Borucin (5), Pietraszyn (5) \\
\hline Lamczyk & Borucin (11), Tworków (10) \\
\hline Lamla & Krzanowice (42), Tworków (5), Borucin (5) \\
\hline Lasak & $\begin{array}{l}\text { Pietrowice Wlk. (6), Krzanowice (10), Borucin (16), Owsiszcze (38), } \\
\text { Tworków (31), Bieńkowice (5), Krzyżanowice (18) }\end{array}$ \\
\hline Latton & Tworków (5) \\
\hline
\end{tabular}




\begin{tabular}{|c|c|}
\hline Lokocz & Krzanowice (10) \\
\hline Łopocz & Tworków (5) \\
\hline Maindok & Pietraszyn (10), Krzanowice (5), Owsiszcze (5) \\
\hline Maisik & Tworków (5), \\
\hline Martinus & Samborowice (6), Bieńkowice (5) \\
\hline Matioszek & Krzanowice (16), Tworków (5) \\
\hline Mludek & Pietrowice Wlk. (29) \\
\hline Morawiec & Tworków (21), Nieńkowice (5) \\
\hline Mrazek & Borucin (5), Lekartów (7) \\
\hline Nawrat (Nawrath) & $\begin{array}{l}\text { Chróścielów (9), Dzierżkowice (5), Samborowice (11), Bieńkowice } \\
\text { (5), Owsiszcze (5), Krzanowice (5) }\end{array}$ \\
\hline Newerla & Pietrowice Wlk. (34) \\
\hline Niewiara & Samborowice (22), Pietraszyn (10), Pietrowice Wlk. (6) \\
\hline Newrzela & Borucin (5) \\
\hline $\begin{array}{l}\text { Obruśnik } \\
\text { (Obrusnik) }\end{array}$ & Borucin (11), Krzanowice (10), Owsiszcze (5), \\
\hline Paletta (Paleta) & Pietrowice Wlk. (34) \\
\hline Palisa & Pietrowice Wlk. (11) \\
\hline Plura & Samborowice (33), Pietrowice Wlk. (6) \\
\hline Popela & Bieńkowice (21), Krzanowice (5), Tworków (5) \\
\hline Pospieszyl & Głubczyce (16), Branice (14), Kietrz (5) \\
\hline $\begin{array}{l}\text { Prochaska } \\
\text { (Prohaska) }\end{array}$ & Tworków (15), Branice (5) \\
\hline Purszke (Purschke) & $\begin{array}{l}\text { Lisięcin (8), Głubczyce (4), Raków (18), Sucha Psina (9), Kietrz (5), } \\
\text { Pietraszyn (5) }\end{array}$ \\
\hline Riemel & Krzanowice (31), Borucin (5) \\
\hline Sbeczka & Owsiszcze (22), Głubczyce (7) \\
\hline Sichma & Borucin (37) \\
\hline Sławik & Krzanowice (68), Samborowice (28), Borucin (16), Pietrowice (6) \\
\hline Stojer & Pietrowice Wlk. (6), \\
\hline Strachota & Pietraszyn (5), Tworków (5) \\
\hline Stuchły & Owsiszcze (5), Tworków (10), Bieńkowice (5) \\
\hline Szamarek & Borucin (32), Krzanowice (10) \\
\hline Szincel & Raków (6) \\
\hline Ternka & Krzanowice (21), Pietraszyn (10), Borucin (5) \\
\hline Tunk & Samborowice (11) \\
\hline Uliczka & Branice (5), Turków (11), Bieńkowice (11), Borucin (5) \\
\hline Wasiczek & Krzanowice (10), Samborowice (6), Borucin (5) \\
\hline Wieder & Pietrowice Wlk. (23), Krzanowice (10), Tworków (10), Tłustomosty (9) \\
\hline Witasek & Borucin (5), Owsiszcze (5) \\
\hline Wyrchowy & Krzanowice (5), Samborowice (6) \\
\hline $\begin{array}{l}\text { Wyszkoni } \\
\text { (Wyszkoń) }\end{array}$ & Tworków (5), Krzanowice (5) \\
\hline Zajczek & Baborów (16), Dzielów (6) \\
\hline Źrały & Głubczyce (4) \\
\hline
\end{tabular}

Źródło: http://nazwiska-polskie.pl/. 
We wspomnianych trzech gminach powiatu raciborskiego, na obszarze tradycyjnego osadnictwa Morawców dominował dialekt laski. Jego oddziaływanie było na tyle silne, że stał się on również językiem mówionym dwu sąsiednich wsi śląskich (Tworków, Bieńkowice), a w kilku innych (np. Rudyszwałd, Krzyżanowice, Bojanów, Wojnowice, Cyprianów, Lekartów) zaznaczały się dość silne jego wpływy (Dejna 1948). Na tym obszarze widać również rozpowszechnienie nazwisk charakterystycznych dla Moraw lub Czech, które w pozostałej części Polski występują sporadycznie. Wyjątkiem są duże i średnie miasta Górnego Śląska, co należy uznać za wynik migracji Morawców do miast. Nazwiska te występują nie tylko we wsiach tradycyjnie morawskich: Owsiszcze, Krzanowice, Borucin, Pietraszyn, Pietrowice Wielkie, Samborowice, ale również w sąsiednich wsiach śląskich, przede wszystkim we wspomnianych Tworkowie oraz Bieńkowicach. Niektóre nawet przede wszystkim tam (np. Lasak, Kretek, Cziuraj, Chrzibek, Friedek, Hawranek, Prochaska, Stuchły, Witeczek).

To ostatnie zjawisko może wskazywać, że rozpowszechnienie się tam dialektu laskiego wynika nie tylko z kontaktów obu społeczności, ale również ze związków rodzinnych i procesu napływu osadników morawskich w przeszłości. Może to potwierdzać również występowanie nazwiska Morawiec, którego brak w sąsiednich wioskach morawskich. Było ono niewątpliwie nadawane przybyszom z Moraw lub ludziom mającym jakiś związek z Morawami. Na podstawie tych przesłanek można postawić tezę, że mieszkańcy Tworkowa i Bieńkowic nie tylko mówili dialektem laskim, ale w dużym stopniu (jeżeli nie w większości) są pochodzenia morawskiego (potomkami osadników z Moraw).

Ten stan rzeczy znajduje potwierdzenie w innych źródłach. Zdaniem Z. Tobjańskiego (1994), w sąsiednich, lecz śląskich, Krzyżanowicach w 1724 r. było 15 gospodarzy (w tym dziewięciu Morawian) i 42 zagrodników (w tym 31 Morawian). Na przełomie XVIII i XIX w. osiedliło się tu jeszcze 18 rodzin czeskich. W Tworkowie wśród 24 gospodarzy i komorników dziewięciu gospodarzy było Czechami, a w Bieńkowicach wśród 48 gospodarzy i sześciu zagrodników było odpowiednio sześciu i pięciu osadników czeskich. Autor nie podaje jednak - tak jak dla Krzyżanowic - liczby miejscowej ludności morawskiej. Z innej strony w historycznie morawskich Pietrowicach Wielkich w 1798 r. było 118 gospodarzy Polaków i tylko 43 gospodarzy Morawian (Tobjański 1994).

Ludność pogranicza morawsko-śląskiego była więc wymieszana, a dodatkowo napływali nowi osadnicy czescy. Tym należy więc m.in. tłumaczyć brak zbieżności między historyczną granicą śląsko-morawską a granicą językową lasko-śląską. W północnej części głubczyckiego w niektórych miejscowościach (Dzielów, Tłustomosty, Sułków, Dziećmierzów) musiały przeważać wpływy śląsko-polskie. W powiecie raciborskim dominowały natomiast wpływy lasko- 
-morawskie i czeskie. O ostatecznym przebiegu granicy językowej zadecydowały jednak nie tylko demograficzne czynniki. Duże znaczenie odgrywały niewątpliwie uwarunkowania historyczno-administracyjne, z którymi wiązał się m.in. język używany w kościele. $Z$ tego powodu gwara morawskich Pietrowic Wielkich, pomimo historycznej przewagi ludności uważanej za Polaków, jest zaliczana do dialektu laskiego, natomiast gwara śląskich Krzyżanowic, pomimo dużego udziału Morawian i osadników czeskich w przeszłości, zaliczana jest przez większość językoznawców do dialektu śląskiego. Podobnie jest z innymi śląskimi miejscowościami tego pogranicza, które choć wykazują wpływy morawskie (Cyprianów, Lekartów, Rudyszwałd), i spotkać w nich można czesko-morawskie nazwiska, pod względem językowym zaliczane są do obszaru dialektu śląskiego. Przypadek Bieńkowic i Tworkowa wskazuje jednak, że uwarunkowania historyczno-administracyjne (wzmocnione językiem używanym w kościele) nie zawsze okazywały się dominujące. Być może znaczący napływ ludności morawskiej (potwierdzony nazwiskami) łączył się tu ze szczególnie silnymi kontaktami z sąsiednimi wsiami morawskimi. W wyniku tego procesu uformowała się tu grupa Ślązaków posługujących się dialektem laskim.

Kwestie językowe nie miały jednak decydującego wpływu na tożsamość miejscowej ludności. Mieszkańcy miejscowości śląskich, nawet jeżeli mówili dialektem laskim, uważali się i byli uważani za Ślązaków, podczas gdy mieszkańcy miejscowości morawskich, choć często posługiwali się dialektem śląskim, uważali się i byli uważani za Morawian (Morawców). Jeszcze innymi torami rozwijała się świadomość narodowa mieszkańców tego pogranicza, co wynikało przede wszystkim z oddziaływania kultury i państwa niemieckiego, później zaś również polskiego. Do dziś duża część miejscowej ludności rodzimej, zarówno morawskiej, jak i śląskiej, w czasie spisów ludności deklaruje narodowość niemiecką. Inni uważają się za Ślązaków. Należy również przypuszczać, że podobnie jak w przypadku części opolskich Ślązaków także u części Morawców rozwinęła się polska świadomość narodowa. W latach 90. XX w. dotyczyło to ok. $20 \%$ Ślązaków zamieszkujących województwo opolskie (Berlińska 1998).

Wśród gmin „morawskich” powiatu raciborskiego największy udział mieszkańców deklarujących narodowość niemiecką zanotowano w Krzanowicach, a więc tam, gdzie ludność morawska przeważa nad śląską. Być może etniczna odrębność Morawian względem Polaków i Ślązaków sprzyjała deklarowaniu narodowości niemieckiej. Potwierdzeniem tej tezy może być również wyraźniejsza przewaga deklaracji niemieckich nad śląskimi w Krzanowicach, w porównaniu z sąsiednimi gminami. Podobna tendencja uwidacznia się również w powiecie głubczyckim. W tamtejszej gminie Baborów, w całości morawskiej, 
choć polskojęzycznej, przewaga deklaracji niemieckich nad śląskimi była jeszcze wyraźniejsza (tab. 2). W tym ostatnim przypadku istotną rolę może jednak odgrywać peryferyjne położenie gminy i bezpośrednie sąsiedztwo z napływową ludnością polską (a wcześniej z niemiecką).

Z uwagi na brak adekwatnych statystyk trudno oszacować obecną liczebność ludności morawskiej w Polsce. Minimalną wielkością jest najprawdopodobniej zsumowana liczba deklaracji śląskich i niemieckich z 2002 r. w polskiej części historycznych Moraw. Było ich ok. 4,5 tys. Maksymalną liczbą jest tu ogólna liczba mieszkańców wsi morawskich, które zachowały rodzimą ludność, bo przecież duża część Morawców mogła zadeklarować narodowość polską. Należy do tego doliczyć jeszcze blisko 500 osób żyjących w rozproszeniu w powiecie głubczyckim. Daje to razem ok. 10,5 tys. osób, które mogłyby uważać się za Morawców. Dochodzi do tego ok. 4 tys. mieszkańców Tworkowa i Bieńkowic, którzy są morawskiego pochodzenia i posługują się dialektem laskim, choć za Morawców nigdy się nie uważali. Ograniczając się tylko do historycznych Moraw i zakładając jakiś wypośrodkowany wariant, można przyjąć, że liczba Morawców sięga tu ok. 7,5 tys.

\section{Współczesne przejawy morawskiej odrębności}

Polonizacja, germanizacja czy też rozwój tożsamości śląskiej nie doprowadził do całkowitego zaniku tożsamości morawskiej. Świadectwem tego jest utrzymujące się poczucie odrębności, widoczne przede wszystkim w gminie Krzanowice. Można domniemywać, że decydujące znaczenie ma tu fakt, że większa część gminy znajduje się na obszarze historycznych Moraw, a miejscowości morawskie (Krzanowice, Borucin, Pietraszyn) są liczniejsze i ludniejsze niż śląskie (Bojanów, Wojnowice). Niemal całkowicie morawski charakter zachował Borucin. Ludzie mówią tu gwarą laską, w kościołach do niedawna używali morawskich kancjonałów i nie znali charakterystycznych dla innych części kraju duszpasterskich wizyt księży (kolęd). Silne oznaki morawskości przetrwały także w samych Krzanowicach, które - z uwagi na wielkość, funkcje administracyjne i obecność kultury morawskiej - można by nazwać stolicą polskich Moraw (znacznie większe Głubczyce, choć historycznie morawskie, nie mają dziś związków z kulturą morawską). Ślązacy od razu rozpoznają odrębność Morawian, bo posługują się oni inną, trudną do zrozumienia, gwarą. Nie mówi się tu droga tylko cesta, nie czereśnie, a hamlary. Latają tu wrany, a nie wrony. Modlitwy nad zmarłym rzykaczki nadal odmawiają po morawsku. Na zakończenie nabożeństw różańcowych śpiewa się morawskie pieśni. Inny jest też strój 
ludowy. Warto również zauważyć, że obszary te formalnie do początku lat 70. XX w. podlegały diecezji ołomunieckiej, choć posługę sprawowali tu księża Administracji Apostolskiej Śląska Opolskiego (Wawoczny, Wasiczek 2010, W Borucinie... 2012).

O żywotności morawskich tradycji mogą świadczyć różne inicjatywy podejmowane przez władze lokalne, stowarzyszenia i indywidualne osoby. W latach 2011-2012 Miejski Ośrodek Kultury w Krzanowicach realizował projekt finansowany ze źródeł Unii Europejskiej „Dwa narody jedna kultura morawska”. Integralnymi częściami tego przedsięwzięcia były: festiwal piosenki polsko-morawskiej, wydanie publikacji „Jako rzadziły i o czym pyrwe śpiwały nasze Omy” - teksty sceniczne kabaretu „Krzanowickie Omy” oraz teksty piosenek i przyśpiewek morawskich, konferencja popularno-naukowa „Tożsamość morawska na pograniczu polsko-czeskim" (oraz publikacja o tym samym tytule), festyn regionalny pod namiotem biesiadnym oraz „Obiektywnie morawskie” warsztaty fotograficzne (Wasiczek 2012). Tematyka morawska jest też obecna w prasie lokalnej, przede wszystkim w czasopiśmie „Krzanowice i okolice”. Cyklicznie obywa się Międzynarodowy Konkurs Gwary Laskiej „Morawske rzadzyni selske hospodyni”. W 2015 r. odbyła się jego dziewiąta edycja. Działają również portale internetowe propagujące morawskie tradycje ${ }^{1}$

\section{Podsumowanie}

Badacze dziejów i odrębności tej społeczności nie mają złudzeń w sprawie szans przetrwania morawskich tradycji w Polsce. Według jednego z nich, Piotra Pałysa, polscy Morawcy przeżywają swoje ostatnie chwile (Strauchmann 2008). Być może więc już niedługo o pochodzeniu mieszkańców tych ziem będą świadczyły jedynie ich morawskie nazwiska.

\section{Literatura}

Berlińska D., 1998, Tożsamość Ślazaków w świetle badań socjologicznych, „Przegląd Zachodni", 3, s. 111-132.

Czapliński M., 2007, Historia Śląska, Wrocław,

Dejna K., 1949, Z najnowszej dialektologii ślaskiej, „Język Polski”, 5 (29), s. 206-215.

Deklaracje narodowościowe $w$ gminach $w 2002 \mathrm{roku}$ : stat.gov.pl/cps/rde/xbcr/gus/nsp 2002 tabl4.xls

\footnotetext{
${ }^{1}$ Na przykład http://kulturamorawska.eu/.
} 
Gawrecká M., 2009, Etniczne, terytorialne i narodowe tożsamości na Ślasku Opawskim, [w:] Rusek H., Drożdż A. (red.), Tożsamość etniczna i kulturowa Śląska w procesie przemian, Prace i Materiały Etnograficzne, 36, Wrocław, s. 305-317.

Janczak J. (red.), 1984, Śląsk w końcu XVIII w., [w:] Atlas historyczny Polski, t. 2, Wrocław.

Kniejski O., Sękowski R. (opr.), 2012, Statut ziemski księstw opolskiego i raciborskiego $i$ innych ziem do nich należacych, Opole.

Kurek J., 1993, Śląsk jako region kulturowy w etnografii, [w:] Zagórski Z. (red.) Struktura współczesnego społeczeństwa Polski w'świetle badań ślaskich, t. 1, Wrocław, s. $51-70$.

Mečiar M., 2007, Sociálni identity autochtonnich obyvatel Hlučinska: Mezigenerační proměny, Dizertační práce, Fakulta sociálních studií Masarykovy univerzity, Brno: http://is.muni.cz/th/23012/fss_d/MM_dizertace_k.pdf

Nazwiska polskie: http://nazwiska-polskie.pl/

Orzechowski K., 2005, Historia ustroju Ślaska, 1202-1740, Wrocław.

Pałys P., 2006, Morawcy w Raciborskiem i Gtubczyckiem w dokumentach polskiej stużby dyplomatycznej z lat 1929-1939, „Zeszyty Historyczne”, 157, s. 131-168.

Pałys P., 2012, Ślask jako wspólna kraina dziejów Polski i Czech - uwagi o polsko-czeskim styku kulturowym/Slezsko jako zemé společných dějin Polska a Česka úvahy o polsko-českém kulturním styku, [w:] Bulanda H. i in. (red.), Kędzierzyn-Koźle - Přerov Portrety miast/Portréty měst, Kędzierzyn-Koźle-Opole, s. 8-21.

Panic I., 2009, Śląsk Cieszyński w czasach plemiennych, [w:] Panic I. (red.), Dzieje Śląska Cieszyńskiego od zarania do czasów wspótczesnych, t. 1: Ślaqsk Cieszyński w czasach prehistorycznych, cz. 1: Ziemia cieszyńska do doby plemiennej, Cieszyn, s. $243-259$.

Rospond S., 1959, Dzieje polszczyzny ślaskiej, Katowice.

Siatkowski J., 1994, Polsko-czeskie kontakty językowe na terenie Polski, „Prace Filologiczne", 39, s. 231-246.

Strauchmann K., 2008, Morawcy przechodza, „Nowa Trybuna Opolska”, 19.01, s. 14.

Szydłowski J., 1991, Sytuacja osadnicza na pótnocnym przedpolu Bramy Morawskiej $w$ dobie plemiennej wczesnego średniowiecza, „Rocznik Cieszyński”, t. 6-7, s. 9-17.

Szymańska M., 2002, Słownictwo gwarowe miejscowości Krzanowice w powiecie raciborskim, praca magisterska, Instytut Polonistyki i Kulturoznawstwa, Uniwersytet Opolski, Opole.

Szymańska M., Słownictwo zanikające w gwarze Krzanowic: http://kulturamorawska.eu/ gwara/

Stieber Z., 1934, Geneza gwar laskich, Kraków.

Tobjański Z., 1994, Czesi w Polsce, Kraków.

Sobotík B., 1946, Naše země, náš lid: Hlubčicko, Ratibořsko, Kozelsko, Matice opavská.

Wasiczek M., 2012, Tożsamość morawska, 7/8 (102/103) lipiec/sierpień 2012, s. 8.

Wasiczek M. (red.), 2012, Tożsamość morawska na pograniczu polsko-czeskim, Racibórz.

W Borucinie dyskutowano o Morawcach, 2012, „Krzanowice i okolice”, 5/6 (100/101) czerwiec/lipiec. 
Wawoczny G., Wasiczek M., 2010, Gmina Krzanowice wczoraj i dziś, Racibórz. Wendt J., 1978, Ziemia Gtubczycka, Opole.

Wrzosek A. (red.), 1955, Górny Śląs: Prace i materiały geograficzne, Kraków.

\section{Moravians (Moravs) in Poland}

\section{Summary}

The paper aims to characterise the Moravian population (Moravs) who lives within the boundaries of Poland as a result of $20^{\text {th }}$-century territorial changes. Representatives of this group differ in their language (Lach dialect) and customs yet, unlike the inhabitants of the Czech Republic, do not identify as Moravians or Czechs. They instead consider themselves as Poles, Germans or Silesians, which stems from the national affiliation of the area between 1742 and 2016. The processes of acculturation may soon lead to the disappearance of the last signs of independence of this ethnic group. Moravian origins will only be seen in last names of some of the population.

Keywords: Moravians, Lach dialect, ethnic independence, Moravia, Silesia, Poland.

Mariusz Kowalski, dr hab. prof. IGiPZ

Instytut Geografii i Przestrzennego Zagospodarowania PAN, 00-818 Warszawa, ul. Twarda 51/55 